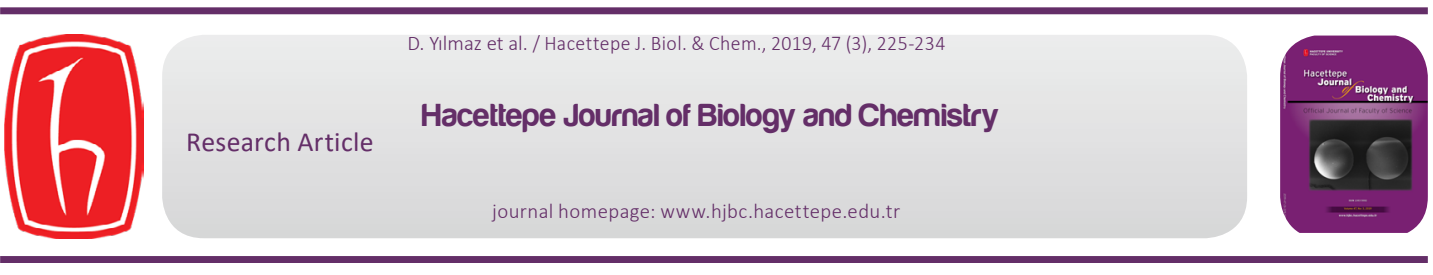

\title{
Ionic Current Rectification in Track-Etched Single Conical Nanopores
}

\section{İz-Aşındırılmış Tekli Konik Nanogözeneklerde İyonik Akım Rektifikasyonu}

\author{
Dürdane Yilmaz ${ }^{1 \oplus}$, Dila Kaya ${ }^{2}$, Kaan Keçeci $^{\circledR}$, Ali Dinler $^{3 \odot}$ \\ ${ }^{1}$ Nanoscience and Nanoengineering Program, İstanbul Medeniyet University, İstanbul, Turkey. \\ ${ }^{2}$ Department of Chemistry, İstanbul Medeniyet University, İstanbul, Turkey. \\ ${ }^{3}$ Department of Applied Mathematics, İstanbul Medeniyet University, İstanbul, Turkey.
}

\section{ABSTRACT}

The ionic current rectification, which is a characteristic behavior of asymmetric nanopores, is an important phenomenon, especially in biomolecule analysis. Rectification in nanopores resembles the diode element in electrical circuits, where the ion current is allowed in only one direction. This behavior depends on certain parameters such as pore geometry, the surface charge density of the pore, ionic concentration of electrolyte, applied potential and pressure. In this study, we investigated the rectification behavior of ionic currents in conical pore experimentally and verified the results theoretically. By altering the $\mathrm{pH}$ value of the electrolyte solution, we have obtained a variety of current-potential (I-V) curves which have different ion current rectification values. We have compared these values with simulation results and figured out an estimate for the surface charge density of the nanopore walls.

\section{Key Words}

Conical nanopore, rectification, ionic current, simulation, finite-element simulations.

\section{öz}

simetrik nanogözeneklerin karakteristiği olan iyon akımı rektifikasyonu (doğrusallıktan sapma) davranışı, özellikle biyomolekül analizinde önemli bir olgudur. Nanogözeneklerdeki bu davranış, elektrik devrelerinde iyon akımının tek yönde gerçekleştiği diyotlara benzemektedir. Bu davranış, gözenek geometrisi, gözenek yüzey yük yoğunluğu, elektrolit iyon konsantrasyonu, uygulanan potansiyel ve basınç gibi belirli parametrelere bağlıdır. Bu çalışmada, konik nanogözenekteki iyonik akımların rektifikasyon davranışları deneysel olarak incelenmiş ve sonuçları teorik olarak doğrulanmıştır. Elektrolit çözeltisinin pH değerini değiştirerek, farklı rektifikasyon değerlerine sahip çeşitli akım-potansiyel (ı-V) eğrileri elde edilmiştir. Bu değerler simülasyon sonuçları ile karşılaştırılarak nanogözenek duvarlarının yüzey yükü yoğunluğu için bir tahminde bulunulabileceği gösterilmiştir.

\section{Anahtar Kelimeler}

Konik nanogözenek, rektifikasyon, iyon akımı, simülasyon, sonlu eleman simülasyonu. 


\section{INTRODUCTION}

R esistive-pulse sensing, which enables label-free detection, is an emerging method used for both the detection and separation of molecules [1-4]. In resistive-pulse sensing, a micron or nano-sized pore is placed between two reservoirs filled with electrolyte solutions and the particles are then electrophoretically driven to the counter electrode [5]. The translocation of the particles causes a momentary drop in the current, which manifests itself as a signal and used for identifying and detecting the particle. Both biological and synthetic nanopores can be implemented in resistive-pulse studies [6-9]. There is an ever growing interest in the fabrication of synthetic nanopores that can efficiently mimic ion channels (biological nanopores), since they are mechanically and chemically robust, durable under high potentials, reproducible and can be tailored in size, shape and surface charge depending on the desired application $[10,11]$. Furthermore, ease of functionalization of the pore walls enables higher sensitivity and selectivity for target molecules [12, 13].

One of the synthetic nanopore fabrication techniques is a track-etching method which is an easy alternative to others for fabricating nanopores with desired sizes and shapes with uniform pore density [14]. In this method, the polymer membranes are first irradiated with accelerated heavy ions, which leaves sensitive tracks inside the membranes along their trajectories. When these tracks are exposed to the etching solution, they turn into nanopores. The etching process is controlled by a stopping solution which neutralizes the etching solution and stops the process. By controlling the number of heavy ions sent to the membrane, one can determine the pore density and even obtain single- nanopore membranes.

The asymmetrical track-etching where only one side of the membrane is treated with the etching solution produces asymmetric (conical) nanopores with one large (base) and one small (tip) opening [15]. Conical nanopores have unique properties that enhance the sensing of molecules. Previous studies have shown that conically shaped track-etched nanopores form a trapping zone at the tip entrance and capture the molecules easier [16] Also, it has been discussed by Siwy that although the electrolyte concentration on both sides of the membrane are identical, the asymmetric nanopores cause rectification on the ionic current [17]. This non-linear behavior depends on the surface charge of the pore and yields asymmetrical current-potential (I-V) curves. The promoting effect of conical geometry was shown for both multiporous $[18,19]$ and single nanopore [20] membranes.

The sensing capabilities of nanopore-based sensors are based on the flow generated by ion transport. In these systems, electrostatic and hydrodynamic interactions between the electrolyte solution and the pore walls are used to amplify or stop the ionic transport [21]. Nanopores have the feature of ionic current rectification (ICR), which is a diode-like behavior [22-24]. The diodelike behavior is the asymmetric response in the I-V curves, similar to a diode in an electrical circuit, where the current is more pronounced in one direction than the reverse direction. For the case of the opposite polarity of the applied potential and pore surface charge, the system behaves like an insulator and the ionic transport, i.e. the current, is reduced. In the first case, counterions are dragged inward by the pore surface charges and working electrode, which cause the ionic current to increase. In the latter case, since the counter ions are rejected by the pore surface charges and cannot move onto the electrode due to the opposite polarity of the applied potential, the ionic current decreases. As a result of the change in polarity, the concentration polarization (i.e. ionic enrichment/depletion) occurs at the pore openings which results in the rectification.

Studies have revealed that the ICR behavior substantially depends on asymmetry of the pore geometry [2528], the non-uniform charge distribution in conical [29] and cylindrical pores [29, 30], applied pressure [24], applied electrical potential [31, 32] and salt concentration $[32,33]$. All the models of ICR are based on interactions of the ions passing through the narrow pores with the excess surface charge on the pore wall [22]. This interesting behavior has been studied from different aspects, such as, whether the ICR is the indigenous behavior of the conical pores with fixed surface charge $[34,35]$, or it results from the non-uniform ionic distribution around the pore tip [36-38]. The latter one has been verified by applying different $\mathrm{pH}$ at both ends of the cylindrical pore [22] which yields rectification behavior. This demonstrates that the rectification does not depend on the pore material but the electrostatic asymmetry of ions in the pore. This also reveals why the rectification behavior is an inherent function of the asymmetric conical pores. 
Asymmetric ionic interactions can be explained as the ionic depletion and accumulation effect [39] which is directly related to the electrical double layer (EDL) overlap. Here, the effective parameter is the surface charges [40]. They dominate the pore selectivity and form the depletion and enrichment region at the pore openings under the applied potential and medium concentration. Namely, for high ionic concentration, EDL thickness decreases as a result of screening by excess ions or vice versa, and yields the occurrence of enrichment/depletion, respectively [41].

To clarify the leading causes that lie behind the ICR occurrence, another important statement has been identified is the comparable size between the pore tip diameter and EDL [42-44]. This condition yields a cause and effect relation between the excess ions and pore shape. As the pore size grows, since the EDL also gets relatively thinner [24] (non-overlapping), rectification behavior becomes weak. For long pores, the whole pore length has to be considered in order to capture the full picture of physical phenomena underlying the ICR behavior in conically shaped pores, [45]. It was revealed the selectivity decreases with the pore radius and increases with the surface charge density as expected [46]. However, the resulting ion selectivity decreased in short channels faster than in long ones which are mostly dependent on the applied voltage. To provide the highest ionic selectivity, the channels should possess not only a very small diameter (and highly charged walls) but also have to be quite long and pore tip radius needs to be in the order of the Debye length [40].

In this study, we have prepared conical nanopores in poly(ethylene terephthalate) (PET) membranes by track etching method and investigated the conical pore's rectification behavior experimentally. To verify the experimental results theoretically, we have used the method which was developed to estimate the particle surface charge [47]. We have altered the assumed surface charge until the simulations match the experimental results in order to get an estimate on the surface charge of the pore at various $\mathrm{pH}$ values. This was achieved by correlating the rectification factor values of experimental I-V curves with the theoretically obtained ones

\section{MATERIALS and METHODS}

\section{Experimental}

PET membranes (3 cm diameter, $12 \mathrm{~mm}$ thickness) irradiated with heavy ions (i.e., $\mathrm{Au}$ ion, $11.4 \mathrm{MeV}$ ) at various ion densities were provided by Gesellshaft für Schwerionenforschung (GSI, Darmstadt- Germany). The membranes had been irradiated with multiple (i.e. 108 ion $\left./ \mathrm{cm}^{2}\right)$ or single ions. All the membranes were exposed to UV irradiation overnight $(\lambda=320 \mathrm{~nm})$ to saturate the damages in tracks and enable a more homogeneous pore size distribution. Sodium hydroxide $(\mathrm{NaOH})$, formic acid $(\mathrm{HCOOH})$, potassium chloride $(\mathrm{KCl})$ and hydrochloric acid $(\mathrm{HCl})$ were purchased from Sigma Aldrich and used as received without further purification. All solutions were prepared using deionized water (Millipore Direct-Q 5, Millipore Co.).

\section{Track-Etching and Pore Size Calculations}

Asymmetric chemical etching whose conditions were discussed previously was applied to obtain conically shaped nanopores [11]. The membrane was placed between the two sides of a conductivity cell with the UVtreated side facing the etching solution of $9 \mathrm{M} \mathrm{NaOH}$, and the other facing stopping solution which is comprised of $1 \mathrm{M} \mathrm{HCOOH}$ and $1 \mathrm{M} \mathrm{KCl}$. A transmembrane potential of $1 \mathrm{~V}$ was applied using Pt electrodes and the breakthrough moment (where there is a sharp increase in the current) was monitored. The etching was continued for two hours and the etching solution was replaced with the stopping solution for neutralization. Lastly, the membranes were washed with di. water to remove possible residues.

The base diameter of the membrane was directly determined from SEM images of multipore membranes and an average of 20 nanopore diameters were taken into consideration. In order to determine the tip diameter of the obtained pores, single pore membranes were etched under the same conditions as the multipore membranes and the tip diameter was electrochemically determined using these single-pore membranes. The single pore membrane was placed in a conductivity cell and both sides of the cell was filled with an electrolyte solution (i.e. $1 \mathrm{M} \mathrm{KCl}$ in $10 \mathrm{mM}$ phosphate buffer). $\mathrm{Ag}$ / $\mathrm{AgCl}$ electrodes were immersed into the cells and potential was stepped $50 \mathrm{mV}$ between $+1 \mathrm{~V}$ and $-1 \mathrm{~V}$ using a Keithley 6487 picoammeter /voltage source. The tip diameter was calculated by using Eq. 1:

$$
\mathrm{R}=\frac{4 \rho \mathrm{l}}{\pi d_{\text {tip }} d_{\text {base }}}
$$


According to Eq. 1, the resistance of the nanopore (R) is directly dependent to the conductivity of the solution $(\rho)$, length of the pore $(I)$, and tip and base diameters (dtip and dbase). R-value was determined from the slope of the I-V curves. The average of three measurements was used for the calculations. The conductivity of the solution was measured with a conductivity meter (Mettler-Toledo FE 30, Colombus, OH, USA).

\section{Finite Element Simulations}

Steady-state finite-element simulations were performed to provide a more quantitative description of the experimental results. By using COMSOL Multiphysics v.4.4 software (COMSOL, Inc.) the Poison equation $\nabla^{2} E=-\frac{\rho}{\varepsilon_{r} \varepsilon_{0}}=-\frac{\mathrm{Fa}}{\varepsilon_{r} \varepsilon_{0}} \sum_{i} z_{i} c_{i}$ (where $E, \rho, \varepsilon_{r}$, $\varepsilon_{0}$, Fa are the electric potential, the electric charge density, $=80,=8.854 \times 10-12 \mathrm{~F} / \mathrm{m}, \mathrm{Fa}=96485 \mathrm{C} / \mathrm{mol}$ are the relative permittivity, the dielectric constant and the Faraday constant, respectively. and are the valence and concentration of the ith ionic species, respectively) and the Nernst-Planck equation $\nabla \cdot\left(-D_{i} \nabla c_{i}-z_{i} \frac{D_{i}}{R T} \mathrm{Fa} \nabla E\right)=-\vec{u} \cdot \nabla c_{i}$ (where is the diffusivity and is the concentration of the ith ionic species; $\mathrm{R}$ is the gas constant, $\mathrm{T}$ is the absolute temperature, $\mathrm{Fa}$ is the Faraday constant and is the velocity vector) are coupled to determine the interaction between the

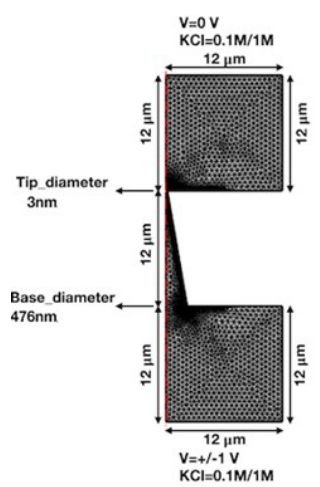

Figure 1. Mesh and boundary conditions of conical pore in rectification simulation.

ionic concentration and the electric potential $[48,49]$.

The diffusion constants of potassium and chlorine ions were set to $1.957 \times 10^{-9} \mathrm{~m}^{2} / \mathrm{s}$ and $2.03 \times 10^{-9}$ $\mathrm{m}^{2} / \mathrm{s}$, respectively. Mobility in the electric field ( $\mathrm{s}$

$\mathrm{mol} / \mathrm{kg})$ was calculated by $D_{i} / R T$ Zero normal flux boundary condition is employed at all walls, $\mathbf{n} \cdot\left(-D_{i} \nabla c_{i}-z_{i} D_{i} /(R T) \mathrm{Fa} \nabla E\right)=0$ where is the normal vector to the surface.

Axially symmetric geometry is applied in calculations and the electric field, electrolyte concentration and

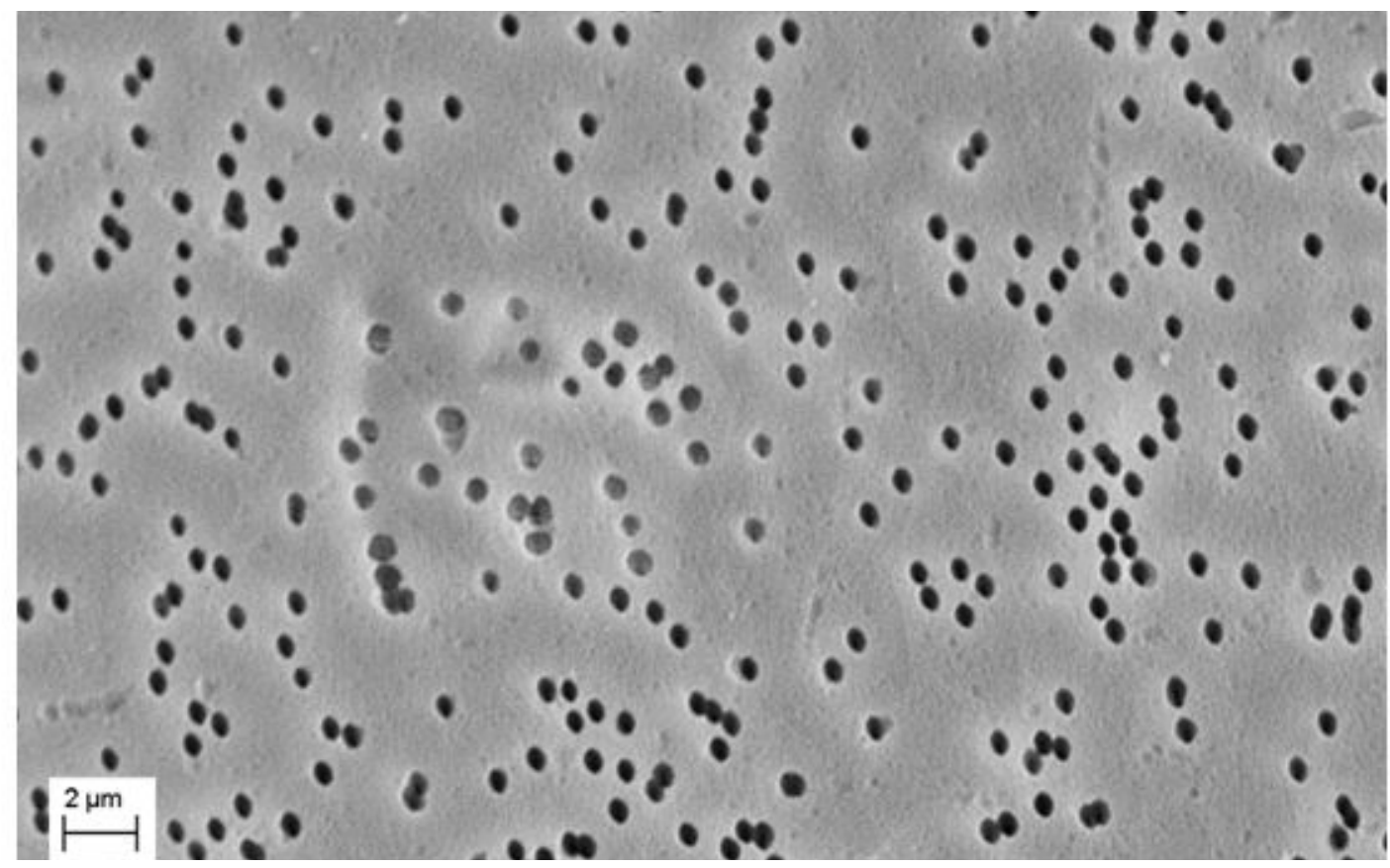

Figure 2. SEM image of multiporous PET membrane at $10 \mathrm{~K}$ magnification. 


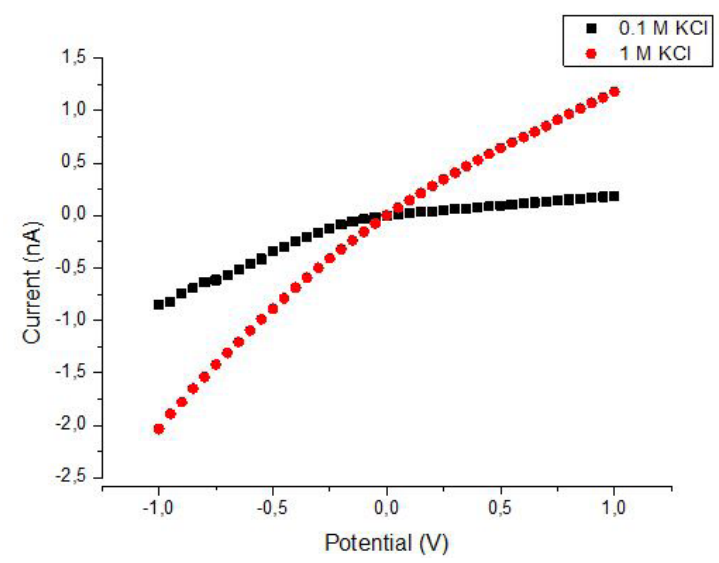

Figure 3. I-V curves of a single conical PET nanopore in 0.1 $\mathrm{M}$ and $1 \mathrm{M} \mathrm{KCl}$.

flow field are obtained in the half-plane. The model also takes into account the electro-osmotic flow and the formation of the electrical double layer at the pore walls. Also, electrical field strength, ion concentration variation inside and around the pore and ion current flow are compared. Simulations were computed in laptop (Intel Core i5-2520M 1.6 GHz, 4 GB RAM).

Pore parameters were specified as following; potentials were applied between +/-1V and pore width-thicknesslength $12 \mu \mathrm{m}$ as shown in Figure $1 . \mathrm{KCl}$ concentration was $0.1 \mathrm{M}$, pore orifice diameter $3 \mathrm{~nm}$ and pore base diameter $476 \mathrm{~nm}$.

\section{RESULTS and DISCUSSION}

In this study, ion current rectification behavior of conical nanopores are investigated in detail based on previous studies on conical pores [50,51]. As explained before $[52,53]$, diode-like behavior occurs in the pore when the current change is evaluated in a certain potential range (i.e. $-1 \mathrm{~V} /+1 \mathrm{~V}$ ). The ionic current increases when a negative potential is applied to the negatively charged pore and the current decreases with the rejection of ions by the pore surface charge when the applied potential is positive. Asymmetric shape effect exists simply because the ionic fluid does not interact with the same amount of surface charge through the pore due to the difference in pore diameter.

Here, axially symmetric pore configuration was considered for observing the variations in the ionic transport and rectification signals. Current, I, was measured by varying the voltage between $+1 \mathrm{~V}$ and $-1 \mathrm{~V}$. The recti- fication behavior was obtained from the measured I -V curves. Rectification is measured by the rectification factor, $R F=I(-1 \mathrm{~V}) / \mathrm{I}(+1 \mathrm{~V})$, which is the ratio between currents at $-1 \mathrm{~V}$ and $+1 \mathrm{~V}$.

\section{Experimental Results}

PET membranes were etched asymmetrically with the etching solution of $9 \mathrm{M} \mathrm{NaOH}$ from the UV treated side only for a conical geometry. After the track-etching process, the base diameter was found to be $476 \pm 39$ $\mathrm{nm}$ from the SEM image of a PET multipore membrane given in Figure 2.

The I-V curves obtained with the same membrane using $0.1 \mathrm{M} \mathrm{KCl}$ and $1 \mathrm{M} \mathrm{KCl}(\mathrm{pH}=7)$ are shown in Figure 3 where ion current rectifications can clearly be observed. Using the slopes of these curves (calculated from the linear part between -0.2 and $+0.2 \mathrm{~V}$ ) and conductivity values of $13.43 \mathrm{mS} / \mathrm{cm}$ and $112.2 \mathrm{mS} / \mathrm{cm}$ for 0.1 $\mathrm{M} \mathrm{KCl}$ and $1 \mathrm{M} \mathrm{KCl}$, respectively, the tip diameter of the pore was calculated to be $3 \mathrm{~nm}$.

Nanopores with smaller diameters rectify the ionic current more than the larger ones as discussed in the Introduction section. For this reason, we have chosen the $3 \mathrm{~nm}$ nanopore to show rectification behavior more clearly.

\section{Effect of $\mathrm{pH}$ on Rectification}

The rectification of the I-V curves by conical pores is directly related to the surface charge of the pore. Since the surface charge of PET is dependent on the carboxylate groups on its pore walls, changing the $\mathrm{pH}$ of the electrolyte solution alters the rectification behavior [54]. With the purpose of exploring the rectification behavior of conical PET nanopores, I-V curves were recorded with $0.01 \mathrm{M}, 0.1 \mathrm{M}$ and $1 \mathrm{M} \mathrm{KCl}$ using a PET nanopore with tip diameter of $\sim 20 \mathrm{~nm}$ and 6 different $\mathrm{pH}$ values ranging from $\mathrm{pH}=1$ to $\mathrm{pH}=11$ (Figure $4-\mathrm{A}$ to $\mathrm{F}$ ).

Figure 4 shows that for neutral or alkali $\mathrm{pH}$ values, PET surface is negative and rectification is observed especially for $0.01 \mathrm{M}$ and $0.1 \mathrm{M} \mathrm{KCl}$. When the $\mathrm{pH}$ is acidic (i.e. $\mathrm{pH}=3$ ) and therefore close to the isoelectric point of PET nanopore, the pore surface becomes neutral and rectification behavior is not observed which is in correlation with previous work [54]. When the $\mathrm{pH}$ is as low as 1 , the surface becomes protonated and the direction of the rectification is reversed. 

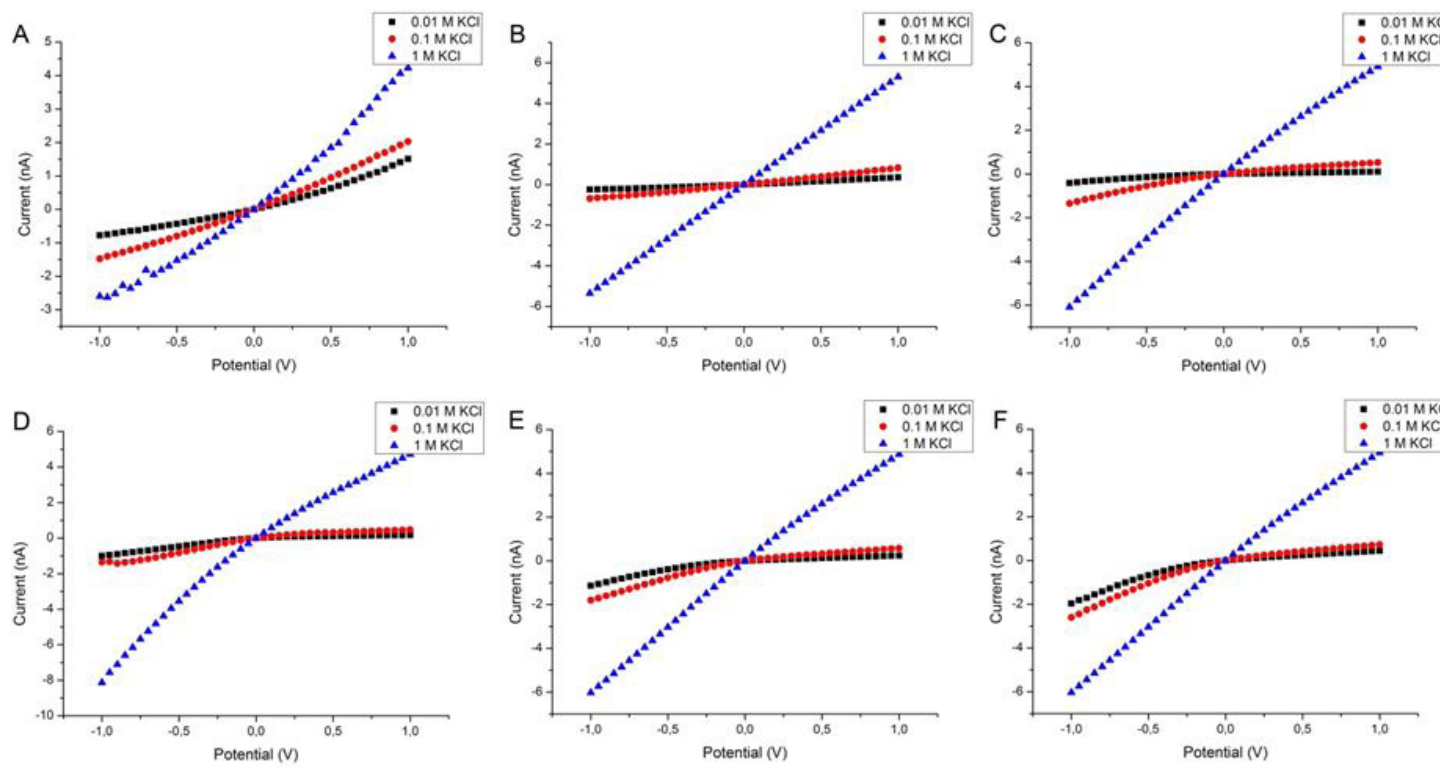

Figure 4. Experimental $\mathrm{I}-\mathrm{V}$ curves obtained in $0.01,0.1$ and $1 \mathrm{M} \mathrm{KCl}$ with various $\mathrm{pH}$ values $(\mathrm{pH}=1(\mathrm{~A}), 3(\mathrm{~B}), 5(\mathrm{C}), 7$ (D), 9 (E), $11(\mathrm{~F}))$.

RF values were also calculated from Eq. 2 and presented in Table 1. It can be concluded that RF values are significantly affected by the voltage at $0.01 \mathrm{M} \mathrm{KCl}$, while RF values are close to .

$$
R F=\left|I_{-1 V}\right| /\left|I_{+1 V}\right| \cdots . . \text { Eq. } 2
$$

\section{Simulation Results}

Figure 5 shows the numerical verification of the experimental data. RF values were obtained as 4.4 and 1.5 for $3 \mathrm{~nm}$ pore using $0.1 \mathrm{M}$ and $1 \mathrm{M} \mathrm{KCl}$, respectively. Numerical results are in good agreement with experimental responses (shown in Figure 3) for which the RF values were calculated to be 4.7 and 1.7 for $0.1 \mathrm{M}$ and $1 \mathrm{M} \mathrm{KCl}$, respectively. Since there is a direct correlation between experimental and theoretical data, we can assume that the surface charge of the actual pore in $\mathrm{pH}=7$ medium is about the same as the one used in the simulations, which is $-0.01 \mathrm{C} / \mathrm{m}^{2}$. This finding indicates that surface charge density can be estimated from simulations, which then can be used to predict I-V behavior.

At narrow (small) conical pores, as the concentration of the electrolyte solution increases, rectification becomes weaker due to the reduction in the EDL thickness. This behavior manifests itself as a more linear response (RF value is close to 1 ) for $1 \mathrm{M} \mathrm{KCl}$.

\section{Concentration Distribution of Potassium lons in the Pore}

Figure 6 represents the concentration distribution of potassium ions in the conical pore with tip diameter 20 $\mathrm{nm}$ for both $0.1 \mathrm{M} \mathrm{KCl}$ and $1 \mathrm{M} \mathrm{KCl}$ mediums. In Figure $6 \mathrm{a}$ and Figure $6 \mathrm{~b}$, rectification is clearly observed around the pore tip zone, namely in the range of $23.97 \mathrm{~nm}$ - $24.02 \mathrm{~nm}$, between the $-1 \mathrm{~V} /+1 \mathrm{~V}$ potential range. As shown in Figure 6 a with $+1 \mathrm{~V}$ applied potential, positive electrode rejects and pushes the cations towards the negatively charged pore while pulling anions toward itself. This state causes the ionic decrease around the tip and resists the ionic flow. In Figure $6 \mathrm{~b}$ at $-1 \mathrm{~V}$, both

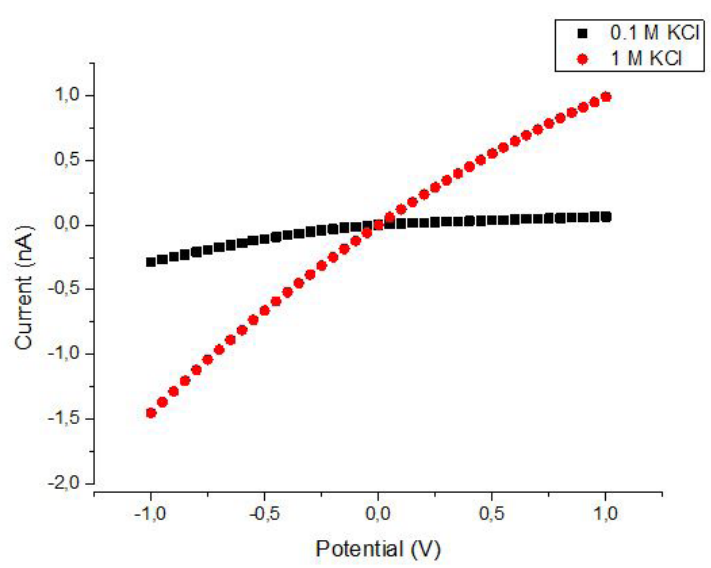

Figure 5. Simulation results of I-V curves of single conical nanopore ( $3 \mathrm{~nm}$ tip diameter) in 0.1 and $1 \mathrm{M} \mathrm{KCl}$. 
Table 1. Rectification factors (RF) obtained with $0.01 \mathrm{M}, 0.1 \mathrm{M}$ and $1 \mathrm{M} \mathrm{KCl}$ at various $\mathrm{pH}$ values.

\begin{tabular}{|c|c|c|c|}
\hline \multicolumn{4}{|c|}{ KCl Concentration (M) } \\
\hline $\mathrm{pH}$ & 0.01 & 0.1 & 1 \\
\hline 1 & 0.51 & 0.73 & 0.61 \\
\hline 3 & 0.68 & 0.83 & 1.01 \\
\hline 5 & 3.90 & 2.59 & 1.24 \\
\hline 7 & 5.93 & 2.92 & 1.73 \\
\hline 9 & 4.63 & 3.13 & 1.24 \\
\hline 11 & 4.40 & 3.57 & 1.22 \\
\hline
\end{tabular}

the negative electrode and the negatively charged pore pushes the anions which in response enhances the potassium ion density around the tip. The same situation is valid in the case of high concentration $\mathrm{KCl}(1 \mathrm{M})$ as shown in Figure $6 \mathrm{c}$ and Figure $6 \mathrm{~d}$. However, at high concentrations, both the reservoirs and the pore channel concentration is around the initial concentration state (1 M). Namely, if we evaluate numerically, in low concentration medium, potassium ions under the positive applied potential are depleted and the density is obtained as approximately $0.097 \mathrm{M}$ around the narrow region of the pore, as shown in Figure 6 a. In Figure 6 $b$, when the sign of the applied potential is switched to negative, potassium ion density increases around the tip zone and increases to approximately $0.103 \mathrm{M}$. In the higher concentration medium, potassium ions distribution amount around the tip forms as $0.97 \mathrm{M}$ under $+1 \mathrm{~V}$, while at dense concentration and altering the potential sign to the negative, one obtains the increasing potassium medium around the tip region as $1.03 \mathrm{M}$, as can be observed in the Figure $6 \mathrm{c}-\mathrm{d}$, respectively.

\section{Effect of Surface Charge Distribution on Rectification}

In order to predict the pore surface charge, we have used the method generated by Venta et al. [47]. By using the known dimensions from the experimental measurement, we simulated the ionic current change.
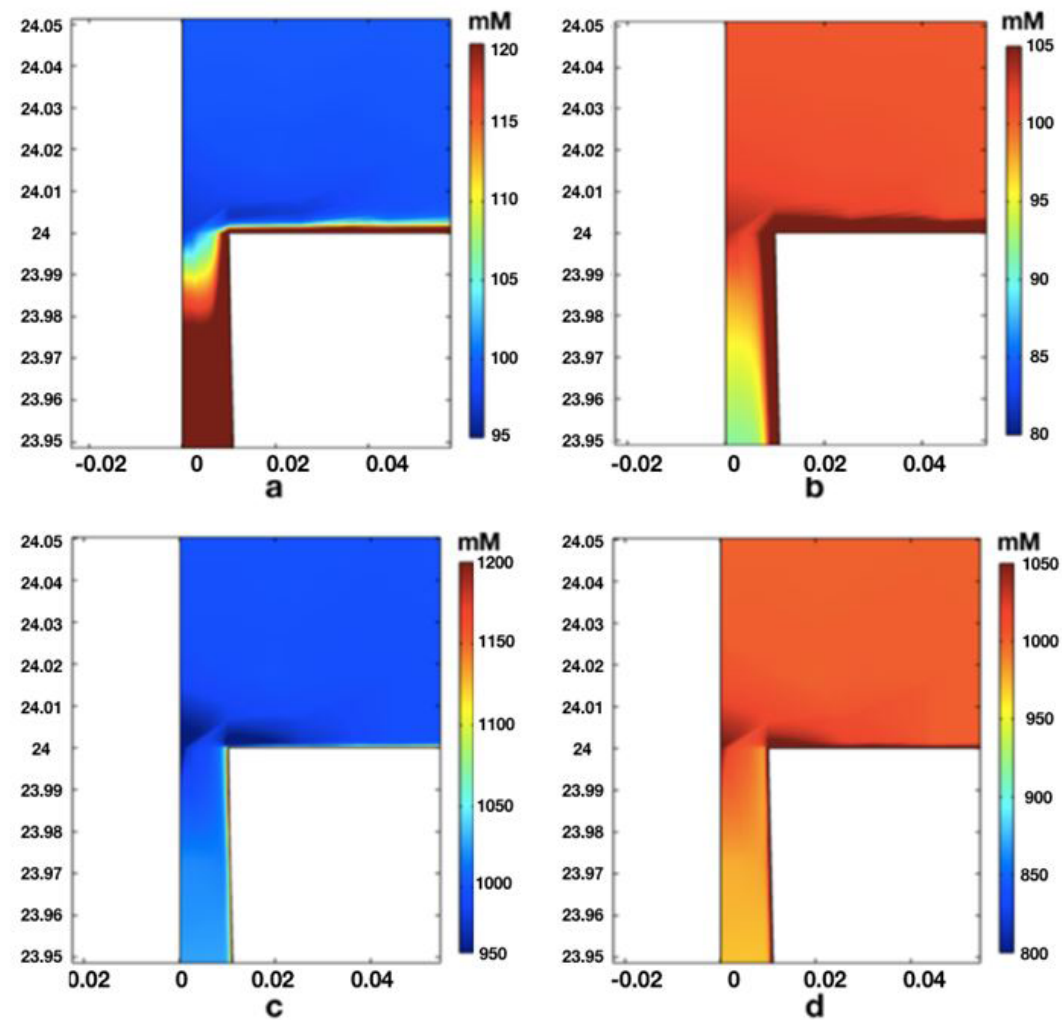

Figure 6. Potassium ion $(K+)$ concentration distribution under applied potential for $+1 \mathrm{~V}, \mathrm{KCl}=0.1 \mathrm{M}(\mathrm{A})-1 \mathrm{~V}, \mathrm{KCl}=0.1 \mathrm{M}(\mathrm{B})+1 \mathrm{~V}$, $\mathrm{KCl}=1 \mathrm{M}(\mathrm{C})-1 \mathrm{~V}, \mathrm{KCl}=1 \mathrm{M}(\mathrm{D})$. 
Table 2 . Simulated $R F$ values obtained with $0.01 \mathrm{M}, 0.1 \mathrm{M}$ and $1 \mathrm{M} \mathrm{KCl}$ with various $S C D$ values.

\begin{tabular}{cccc}
\hline & \multicolumn{3}{c}{$\mathrm{KCl}$ Concentration (M) } \\
\hline $\mathrm{SCD}\left(\mathrm{C} / \mathrm{m}^{2}\right)$ & 0.01 & 0.1 & 1 \\
\hline+0.005 & 0.22 & 0.73 & 0.96 \\
\hline+0.001 & 0.6 & 0.94 & 0.99 \\
\hline-0.005 & 4.5 & 1.36 & 1.03 \\
\hline-0.01 & 4.8 & 1.75 & 1.06 \\
\hline-0.015 & 4.66 & 2.10 & 1.09 \\
\hline-0.02 & 3.83 & 2.26 & 1.11 \\
\hline
\end{tabular}

Then, surface charge value was iteratively altered until the numerical results matched the experimental ones.

We have simulated the RF values with 6 different surface charge density (SCD) values for 0.01, 0.1 and $1 \mathrm{M} \mathrm{KCl}$ concentration. The results are given in Table 2 . When these RF values are compared with the experimental $\mathrm{RF}$ values obtained in different $\mathrm{pH}$ mediums, a similar trend is found. For acidic $\mathrm{pH}$ (i.e. $\mathrm{pH}=1$ and $\mathrm{pH}=3$ ), $\mathrm{RF}$ values were lower than 1 for both experimental and simulation results, which means the surface is indeed protonated and pore walls are positively charged. Similar RF values also indicate that the chosen SCD values mimic the pore conditions in experiments.

At negative SCD values, which correspond to $\mathrm{pH}$ values higher than the isoelectric point of PET, RF values are all higher than 1 in both experimental and simulation data. Furthermore, for $1 \mathrm{M} \mathrm{KCl}$, the results are close to 1 , in accordance with experimental results.

\section{Conclusion}

In this work we have experimentally determined the ion current rectification behavior of conical single nanopores which were fabricated using the track-etching method. We have investigated the ion current rectification of a $3 \mathrm{~nm}$ nanopore both experimentally and theoretically. The calculated RF values were identical and therefore we have concluded the SCD of the pore at $\mathrm{pH}$ $=7$ was $-0.01 \mathrm{c} / \mathrm{m}^{2}$ for this pore. Since ion current rectification is directly related to the surface charge density of the nanopore walls, we have studied the rectification behavior using $\mathrm{KCl}$ solutions with different $\mathrm{pH}$ values for a $20 \mathrm{~nm}$ pore. Experimental and simulation data were matched. Both data showed similar trends against the variation of the voltage and salt concentration. By comparing the rectification factor values, we have estimated the surface charge density of the pore walls cor- responding to a given $\mathrm{pH}$ value. We have shown that in neutral and alkali environment, the pore walls are negative and therefore the rectification is higher. For highly acidic concentrations, however, the pore walls are protonated and the rectification is reversed. We have verified the same behavior in simulations by altering the surface charge density values.

\section{Acknowledgments}

Experimental studies were performed in the Research Laboratory of Engineering and Natural Sciences, Istanbul Medeniyet. D.Y. is supported by the Council of Higher Education (YOK) of Turkey under the 100/2000 Doctoral Scholarship Programme.

\section{References}

1. S. Umehara, M. Karhanek, R.W. Davis, N. Pourmand, Labelfree biosensing with functionalized nanopipette probes, Proc. Natl. Acad. Sci., 106 (2009) 4611-4616.

2. A. Han, M. Creus, G. Schurmann, V. Linder, T.R. Ward, N.F. de Rooij, U. Staufer, Label-free detection of single protein molecules and protein-protein interactions using synthetic nanopores, Anal. Chem., 80 (2008) 4651-4658.

3. S.B. Lee, D.T. Mitchell, L. Trofin, T.K. Nevanen, H. Söderlund, C.R. Martin, Antibody-based bio-nanotube membranes for enantiomeric drug separations, Science, 296 (2002) 21982200 .

4. A.S. Prabhu, T.Z.N. Jubery, K.J. Freedman, R. Mulero, P. Dutta, M.J. Kim, Chemically modified solid state nanopores for high throughput nanoparticle separation, J. Phys-Condens Mat., 22 (2010) 454107.

5. H. Bayley, C.R. Martin, Resistive-Pulse Sensing-From Microbes to Molecules, Chem. Rev., 100 (2000) 2575-2594.

6. Y.X. Wang, K. Kececi, M.V. Mirkin, V. Mani, N. Sardesai, J.F. Rusling, Resistive-pulse measurements with nanopipettes: detection of Au nanoparticles and nanoparticle-bound antipeanut IgY, Chem. Sci., 4 (2013) 655-663.

7. S. Wen, T. Zeng, L. Liu, K. Zhao, Y. Zhao, X. Liu, H.-C. Wu, Highly sensitive and selective DNA-based detection of mercury (II) with $\alpha$-hemolysin nanopore, J. Am. Chem. Soc., 133 (2011) 18312-18317.

8. D. Stoddart, A.J. Heron, J. Klingelhoefer, E. Mikhailova, G. Maglia, H. Bayley, Nucleobase recognition in ssDNA at the central constriction of the alpha-hemolysin pore, Nano Lett., 10 (2010) 3633-3637. 
9. K. Healy, B. Schiedt, Z. Siwy, A.P. Morrison, R. Neumann, Single-molecule DNA transport through individual conical polymer nanopores, Biophys J., 88 (2005) 660a-660a.

10. M. Kühnemund, M. Nilsson, Digital quantification of rolling circle amplified single DNA molecules in a resistive pulse sensing nanopore, Biosens. Bioelectron., 67 (2015) 11-17.

11. K. Kececi, N. San, D. Kaya, Nanopore detection of double stranded DNA using a track-etched polycarbonate membrane, Talanta, 144 (2015) 268-274.

12. M. Ali, S. Nasir, P. Ramirez, J. Cervera, S. Mafe, W. Ensinger, Calcium binding and ionic conduction in single conical nanopores with polyacid chains: model and experiments, ACS Nano, 6 (2012) 9247-9257.

13. M. Ali, I. Ahmed, P. Ramirez, S. Nasir, S. Mafe, C.M. Niemeyer, W. Ensinger, A redox-sensitive nanofluidic diode based on nicotinamide-modified asymmetric nanopores, Sensor Actuat. B-Chem., 240 (2017) 895-902

14. A. Kocer, L. Tauk, P. Dejardin, Nanopore sensors: From hybrid to abiotic systems, Biosens. Bioelectron., 38 (2012) 1-10.

15. D. Kaya, A. Dinler, N. San, K. Kececi, Effect of pore geometry on resistive-pulse sensing of DNA using track-etched PET nanopore membrane, Electrochim. Acta, 202 (2016) 157165

16. S. Lee, Y. Zhang, H.S. White, C.C. Harrell, C.R. Martin, Electrophoretic capture and detection of nanoparticles at the opening of a membrane pore using scanning electrochemical microscopy, Anal. Chem., 76 (2004) 6108 6115.

17. Z. Siwy, lon-current rectification in nanopores and nanotubes with broken symmetry, Adv. Funct. Mater., 16 (2006) 735-746.

18. Q.H. Nguyen, M. Ali, V. Bayer, R. Neumann, W. Ensinger, Charge-selective transport of organic and protein analytes through synthetic nanochannels, Nanotechnology, 21 (2010) 365701

19. D.K. Kaya, Kaan, Transport characteristics of selected dyes through track-etched multiporous pet membranes, Hacettepe J. Biol. Chem., 46 (2018) 1-11.

20. Z. Siwy, P. Apel, D. Baur, D.D. Dobrev, Y.E. Korchev, R Neumann, R. Spohr, C. Trautmann, K.O. Voss, Preparation of synthetic nanopores with transport properties analogous to biological channels, Surf. Sci., 532 (2003) 1061-1066.

21. S. Z. Siwy, S. Howorka, Engineered voltage-responsive nanopores, Chem. Soc. Rev., 39 (2010) 1115-1132.

22. Z.S. Siwy, Ion-current rectification in nanopores and nanotubes with broken symmetry, Adv. Funct. Mater., 16 (2006) 735-746.

23. D. Wang, G. Wang, Dynamics of ion transport and electric double layer in single conical nanopores, J. Electroanal. Chem., 779 (2016) 39-46.

24. W.J. Lan, D.A. Holden, H.S. White, Pressure-dependent ion current rectification in conical-shaped glass nanopores, J. Am. Chem. Soc., 133 (2011) 13300-13303.

25. Z. Siwy, D. Dobrev, R. Neumann, C. Trautmann, K. Voss, Electro-responsive asymmetric nanopores in polyimide with stable ion-current signal, Appl. Phys. A-Mater., 76 (2003) 781-785

26. D. Momotenko, F. Cortés-Salazar, J. Josserand, S. Liu, Y. Shao, H.H. Girault, Ion current rectification and rectification inversion in conical nanopores: a perm-selective view, Phys. Chem. Chem. Phys., 13 (2011) 5430-5440.

27. C. Wei, A.J. Bard, S.W. Feldberg, Current rectification at quartz nanopipet electrodes, Anal. Chem., 69 (1997) 4627 4633.
28. N. Sa, L.A. Baker, Rectification of nanopores at surfaces, J. Am. Chem. Soc., 133 (2011) 10398-10401.

29. R. Yan, W. Liang, R. Fan, P. Yang, Nanofluidic diodes based on nanotube heterojunctions, Nano Lett., 9 (2009) 3820-3825.

30. X. Hou, F. Yang, L. Li, Y. Song, L. Jiang, D. Zhu, A biomimetic asymmetric responsive single nanochannel, J. Am. Chem. Soc., 132 (2010) 11736-11742.

31. D. Momotenko, H.H. Girault, Scan-rate-dependent ion current rectification and rectification inversion in charged conical nanopores, J. Am. Chem. Soc., 133 (2011) 1449614499.

32. H.S. White, A. Bund, Ion current rectification at nanopores in glass membranes, Langmuir, 24 (2008) 2212-2218.

33. L. Cao, W. Guo, Y. Wang, L. Jiang, Concentration-gradientdependent ion current rectification in charged conical nanopores, Langmuir, 28 (2011) 2194-2199.

34. Z. Siwy, Y. Gu, H. Spohr, D. Baur, A. Wolf-Reber, R. Spohr, P. Apel, Y. Korchev, Rectification and voltage gating of ion currents in a nanofabricated pore, EPL (Europhysics Letters), 60 (2002) 349

35. Z. Siwy, P. Apel, D. Baur, D.D. Dobrev, Y.E. Korchev, R. Neumann, R. Spohr, C. Trautmann, K.-O. Voss, Preparation of synthetic nanopores with transport properties analogous to biological channels, Surf. Sci., 532 (2003) 1061-1066.

36. D. Woermann, Analysis of non-ohmic electrical currentvoltage characteristic of membranes carrying a single tracketched conical pore, Nucl. Instrum. Meth. B, 194 (2002) 458-462.

37. D. Woermann, Electrochemical transport properties of a cone-shaped nanopore: high and low electrical conductivity states depending on the sign of an applied electrica potential difference, Phys. Chem. Chem. Phys., 5 (2003) 1853-1858.

38. D. Woermann, Electrochemical transport properties of a cone-shaped nanopore: revisited, Phys Chem Chem Phys, 6 (2004) 3130-3132.

39. Q. Pu, J. Yun, H. Temkin, S. Liu, Ion-enrichment and iondepletion effect of nanochannel structures., Nano Lett., 4 (2004) 1099-1103.

40. C. Kubeil, A. Bund, The role of nanopore geometry for the rectification of ionic currents, J Phys Chem C, 115 (2011) 7866-7873.

41. J.-P. Hsu, T.-W. Lin, C.-Y. Lin, S. Tseng, Salt-dependent ion current rectification in conical nanopores: impact of salt concentration and cone angle, J. Phys. Chem. C, 121 (2017) 28139-28147.

42. J. Cervera, B. Schiedt, R. Neumann, S. Mafé, P. Ramírez, Ionic conduction, rectification, and selectivity in single conical nanopores, J. Chem. Phys., 124 (2006) 104706.

43. W. Sparreboom, A. van den Berg, J.C. Eijkel, Principles and applications of nanofluidic transport, Nature Nanotech., 4 (2009) 713

44. H. Daiguji, P. Yang, A. Majumdar, Ion transport in nanofluidic channels, Nano Lett., 4 (2004) 137-142.

45. J.F. Pietschmann, M.T. Wolfram, M. Burger, C. Trautmann, G. Nguyen, M. Pevarnik, V. Bayer, Z. Siwy, Rectification properties of conically shaped nanopores: consequences of miniaturization, Phys. Chem. Chem. Phys., 15 (2013) 1691716926.

46. I. Vlassiouk, S. Smirnov, Z. Siwy, Ionic selectivity of single nanochannels, Nano Lett., 8 (2008) 1978-1985.

47. K.E. Venta, M.B. Zanjani, X. Ye, G. Danda, C.B. Murray, J.R. Lukes, M. Drndić, Gold nanorod translocations and charge measurement through solid-state nanopores., Nano Lett., 14 (2014) 5358-5364. 
48. K.P. Singh, M. Kumar, Effect of gate length and dielectric thickness on ion and fluid transport in a fluidic nanochannel., Lab on a Chip., 12 (2012) 1332-1339.

49. L. van Oeffelen, W. Van Roy, H. Idrissi, D. Charlier, L. Lagae, G. Borghs, lon current rectification, limiting and overlimiting conductances in nanopores., PloS One., 10 (2015) e0124171.

50. M. Chander, R. Kumar, S. Kumar, N. Kumar, S. Chakarvarti, Investigation of ionic transport through track-etched conical nanopores of PET membrane, Nano, 13 (2018) 1850011.

51. J. Liu, M. Kvetny, J. Feng, D. Wang, B. Wu, W. Brown, G. Wang, Surface charge density determination of single conical nanopores based on normalized ion current rectification, Langmuir, 28 (2011) 1588-1595.
52. R. Karnik, C. Duan, K. Castelino, H. Daiguji, A. Majumdar, Rectification of ionic current in a nanofluidic diode., Nano Lett., 7 (2007) 547-551.

53. K. Zielinska, A. Gapeeva, O. Orelovich, P.Y. Apel, Diodelike properties of single-and multi-pore asymmetric track membranes, Nucl. Instrum. Meth. B, 326 (2014) 131-134.

54. Z. Siwy, P. Apel, D. Baur, D.D. Dobrev, Y.E. Korchev, R. Neumann, R. Spohr, C. Trautmann, K.-O. Voss, Preparation of synthetic nanopores with transport properties analogous to biological channels, Surf. Sci., 532-535 (2003) 1061-1066. 